TAPROBANICA, ISSN 1800-427X. April, 2012. Vol. 04, No. 01: pp. 52-53.

(C) Taprobanica Private Limited, Jl. Kuricang 18 Gd.9 No.47, Ciputat 15412, Tangerang, Indonesia.

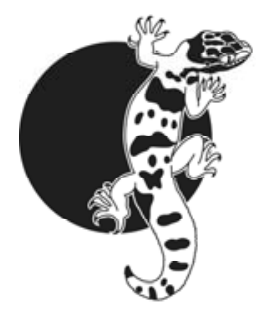

\section{First record of the blue sea slug (Glaucus atlanticus) from Andhra Pradesh - India}

The blue sea slug Glaucus atlanticus Forster, 1777 (Gastropoda, Glaucidae) is a nudibranch that occurs in temperate and tropical oceans throughout the world. It is characterized by a silvery white dorsal surface and dark blue ventral surface. The body is elongate measuring up to $3 \mathrm{~cm}$ and is flattened. The head is small and blunt with a pair of small oral tentacles near the mouth. The cerata or papillae are wing-like and extend laterally from three distinct pairs of peduncles. The papillae are placed in a single row (uniseriate) and may be 84 in total (Forster, 1777). A similar looking glaucid nudibranch, Glaucus marginata (Bergh, 1860), is a bluish-brown nudibranch with bluish underside, and differs from Glaucus atlanticus in bearing four pairs of clusters of papillae that are arranged in more than one row (multiseriate) and may be 139 or more in number (Bergh, 1860). The latter species has been included by some authorities under the genus Glaucilla Bergh, 1860. Presently, both species are listed under Glaucus Poli, 1795 (Burn, 2006; Gofas et al., 2001).

Glaucus atlanticus is rarely seen on shore as it is pelagic except during periods of on-shore winds when they can be found floating in coastal waters and sometimes washed on to beaches. They float partially by means of an air bubble that they have swallowed and stored in their gastric cavity and are able to move toward prey or mates by using their cerata to make slow swimming movements. They eat a variety of drifting prey including the siphonophore Physalia utriculus (Portuguese mano-war) as well as the chondrophores Velella velella and Porpita pacifica (Bayer, 1963; Lalli \& Gilmer, 1989; Thompson \& Bennett, 1969, 1970).

In a recent field survey along the coast of Visakhapatnam District, Andhra Pradesh, India, we observed washed up specimens of Glaucus atlanticus. No vouchers have been collected, but the photo vouchers (NHM.OU.MOLL.PV.1-2012 \& NHM.OU.MOLL.PV.2-2012) (Fig. 1) have been deposited at the Natural History Museum of the Osmania University, Hyderabad, India.

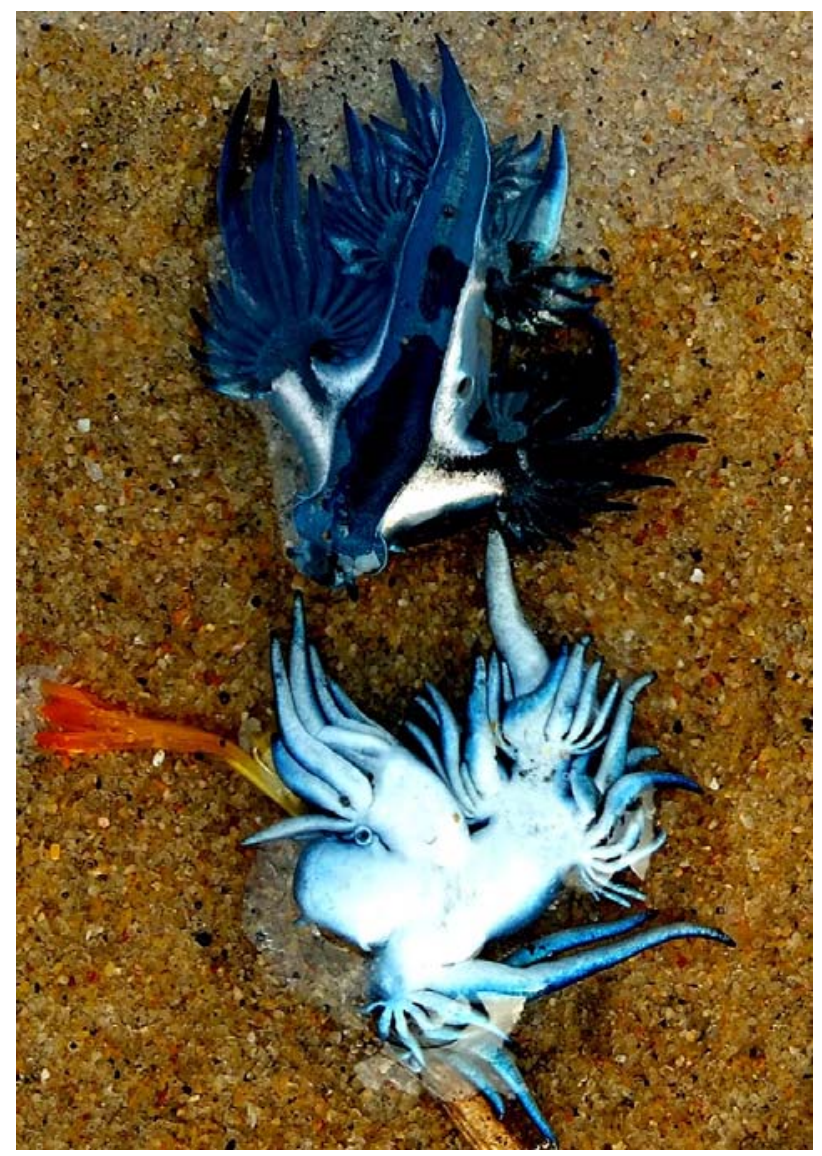

Figure 1: Glaucus atlanticus from Visakhapatnam, Andhra Pradesh, India

This species has been reported from many places (Thompson \& McFarlane, 2008) in tropical and temperate regions, mostly encountered as washedup specimens and sometimes in the seas from 31 marine ecoregions of ten marine realms: Southern Vietnam, Lord Howe and Norfolk Islands (Central Indo-Pacific); Southern Cook/Austral Islands, Hawaii (Eastern Indo-Pacific); Andaman \& Nicobar Islands, Eastern India, South India \& Sri Lanka, Gulf of Aden, East African Coral Coast, Seychelles, Western \& Northern Madagascar (Western IndoPacific); Nicoya, Northern Galapagos Island, 
Eastern Galapagos Island (Tropical Eastern Pacific); Central Kurushio Current (Temperate Northern Pacific); Tweed-Moreton, ManningHawkesbury, Cape Howe, Northeastern New Zealand (Temperate Australasia); Bermuda, Florida, Southern Gulf of Mexico (Tropical Atlantic); Western Mediterranean, Azores Canaries Madeira, Virginia, North Carolina, Northern Gulf of Mexico (Temperate Northern Atlantic); Uruguay - Buenos Aires Shelf (Temperate South America); Natal, Agulhas Bank, Namaqua (Temperate Southern Africa).

In Indian seas, Glaucus atlanticus has previously been documented from Bay of Bengal and off the coast of Nagapattinam, Tamil Nadu, India (GBIF, 2012; Kamalakannan et al., 2010). The presence of the species further north along the coast of Andhra Pradesh reveals that the populations of this species may have moved further in to the Bay of Bengal with more possibilities of the species moving further north of Andhra Pradesh.

\section{Acknowledgements}

We thank the Head of the Department of Zoology, Osmania University, Hyderabad for providing necessary facilities, Department of Biotechnology (Government of India), and University Grants Commission (Government of India) in New Delhi for research grants, C. Aditya Srinivasulu for mapping the species.

\section{Literature cited}

Bayer, F. M., 1963. Observations on pelagic mollusks associated with the siphonophores Velella and Physalia. Bulletin of Marine Science of the Gulf \& Caribbean, 13: 454-466.

Bergh, L. S. R., 1860. Om Forekomsten af Neldefiim hos Mollusker. Vidensk. Meddel. Naturh. Foren. Kjöbenhavn: 309-331+pl.8.

Burn R., 2006. A checklist and bibliography of the Opisthobranchia (Mollusca: Gastropoda) of Victoria and the Bass Strait area, south-eastern Australia. Museum Victoria Science Reports, 10: 1-42.

Forster, G., 1777. A voyage round the world in His Britannic Majesty's sloop, Resolution, commanded by Capt. James Cook, during the years 1772, 3, 4, and 5 by George Forster. Vol. 1: 49.
Gofas, S., J. Le Renard and P. Bouchet, 2001. Mollusca. In: Costello, M. J. et al. (ed.) (2001). European register of marine species: a check-list of the marine species in Europe and a bibliography of guides to their identification. Collection Patrimoines Naturels, 50: 180-213.

GBIF, 2012. Biodiversity occurrence data published by Indian Ocean Node of OBIS (Accessed through GBIF Data Portal, data.gbif.org, 2012-02-29).

Kamalakannan, K., S. Kumaran, S. Balakrishnan, C. Thenmozhi, P. Sampathkumar and T. Balasubramanian, 2010. Occurrence of Glaucus atlanticus and Glaucus marginata (Blue Ocean Slug) from Nagapattinam coastal waters, South east coast of India. International Journal of Current Research, 5: 71-73.

Lalli C. M. and R. W. Gilmer, 1989. Pelagic snails: the biology of holoplanktonic gastropod mollusks. Stanford University Press, California: 259.

Thompson, T. E. and I. Bennett, 1969. Physalia nematocysts: Utilised by mollusks for defense. Science, 166: 1532-1533.

Thompson, T. E. and I. Bennett, 1970. Observations on Australian Glaucidae (Mollusca: Opisthobranchia). Zoological Journal of the Linnean Society of London, 49: 187-197.

Thompson, T. E. and I. D. McFarlane, 2008. Observations on a collection of Glaucus from the Gulf of Aden with a critical review of published records of Glaucidae (Gastropoda, Opisthobranchia). Proceedings of the Linnean Society of London, 178 (2): 107-123.

Submitted: 07 March 2012, Accepted: 16 March 2012 Sectional Editor: Brenden Holland

Bhargavi Srinivasulu ${ }^{1,2}$, C. Srinivasulu ${ }^{1}$ and G. Chethan Kumar ${ }^{1}$

${ }^{1}$ Wildlife Biology Section, Department of Zoology, University College of Science, Osmania University, Hyderabad 500007, India

22E-mail: bharisrini@osmaniawildlife.org 